\title{
РОЗКРИТТЯ ПОТЕНЦІАЛУ ПРИКОРДОННОГО РЕГІОНУ \\ ТА ПРОТИДІЯ АКТУАЛЬНИМ РИЗИКАМ В УМОВАХ РОЗШИРЕНИХ МОЖЛИВОСТЕЙ МІСЦЕВОГО САМОВРЯДУВАННЯ (НА ПРИКЛАДІ ЗАКАРПАТТЯ)
}

Головка А. А.

\section{ВСТУП}

Історія становлення та розвитку інституту місцевого самоврядування в незалежній Україні пов'язана із пошуком найбільш оптимальної та ефективної моделі розподілу повноважень «центр - регіон - громада». Реформа місцевого самоврядування та конструювання нової територіальної організації влади в Україні хоч і зустріли (і продовжують зустрічати) низку перешкод, але все ж в умовах сьогодення більшою частиною громадськості, експертного та наукового середовища визнані як правильний напрям пошуків. Питання, пов'язані із можливістю місцевих спільнот самостійно вирішувати завдання місцевого значення та розпоряджатися наявними ресурсами, особливо актуальне для прикордонних регіонів, зокрема для регіону Закарпаття, де на процес децентралізації накладаються специфічні географічні, економічні, гуманітарні та етнонаціональні чинники.

Розвиток Закарпаття, як і будь-якого прикордонного регіону (а саме сприяння економічному благополуччю населення, соціальній стійкості, розвиток господарства, інфраструктури та логістики, захист довкілля) це насамперед «іміджевий показник». Прикордоння $\epsilon$ своєрідною «візитівкою» країни, свідченням поточного рівня розвиненості регіонів, ефективності регіональної політики, що впливає на сфери транскордонного співробітництва, інвестиційну привабливість регіону, характер міжнародних комунікацій. Крім того, характер та інтенсивність розвитку прикордоння $є$ однією з основних детермінант суспільно-політичної стабільності, оскільки істотні соціальноекономічні диспропорції між прикордонними територіями та географічно близькими регіонами сусідніх країн можуть спричинити як соціальні (масова трудова міграція), так і політичні наслідки (політична нестабільність, дезінтеграційні тенденції, які можуть посилюватися внаслідок зовнішнього впливу).

Варто підкреслити, що модель взаємовідносин «центр прикордоння» характеризується численним недоліками та недостатньою ефективністю, а частина стратегічних орієнтирів 
регіональної політики потребує переосмислення 3 урахуванням можливостей, які дає децентралізація. Насамперед варто наголосити на «архаїчності» та стереотипності сприйняття Закарпаття та інших західноукраїнських прикордонних регіонів (винятком тут є тільки Львівщина) як апріорі депресивних і дотаційних, які через низку факторів залишатимуться «проблемною периферією».

Істотні труднощі також створює домінуюча серед представників місцевої еліти орієнтація на задоволення локальних та корпоративних інтересів на противагу національно значимим цілям - здебільшого серед місцевих еліт прикордоння наявне бажання «ізолюватися» та уникати жорсткого контролю 3 боку Києва, встановлювати «свої правила» на місцях (умовно це виглядає, як осучаснена форма «феодальної роздробленості»).

Серед імовірних наслідків реформи місцевого самоврядування та територіальної організації влади - усунення стереотипності із порядку денного регіональної політики та зростання участі громад у процесах врядування (замість домінування в політичному житті інтересів місцевих еліт та їх лобістів). Розширення повноважень і бюджетних можливостей органів місцевого самоврядування в умовах нової територіальної організації влади створює платформу для посилення ініціативності громад та використання наявних конкурентних переваг, у випадку Закарпаття - географічної близькості до $\mathrm{CC}$, позитивного екологічного іміджу, досвіду та умов для розвитку транскордонного співробітництва.

\section{1. Пошук рушіїв регіонального розвитку в умовах розширення можливостей місцевого самоврядування}

Як уже було згадано у вступній частині матеріалу, поточна модель взаємовідносин «центр - прикордоння» характеризується наявністю недоліків та «архаїзмів», а тому на часі переосмислення підходів до забезпечення сталого розвитку прикордонних регіонів із використанням можливостей, наданих децентралізацією. В цьому контексті слід наголосити на необхідності утвердження інклюзивного niдxoдy до регіональної політики (застосування такого підходу $\epsilon$ актуальним не тільки для прикордоння), який має замінити все ще існуючі елементи екстрактивного підходу.

Для розуміння відмінності зазначених вище підходів варто спиратися на ключові положення концепції Д. Аджемоглу та Д. Робінсона ${ }^{1}$, застосовати їх щодо визначення шляхів розкриття

${ }^{1}$ Acemoglu D., Robinson J. Why Nations Fail: The Origins of Power, Prosperity and Poverty. New-York : Crown Publishers. URL: http://norayr.am/collections/books/WhyNations-Fail-Daron-Acemoglu.pdf. 
потенціалу регіонів та окремих громад, підвищення ефективності управління на локальному рівні:

- інклюзивний підхід - створення умов для участі всіх соціальних і національних груп у процесі управління, чіткі правові гарантії та рівні права, безбар'єрність для економічної активності, посилення взаємозв'язків між суб'єктами (в цьому випадку - між громадами) та спільна координація в досягненні цілей, які становлять спільний інтерес;

- екстрактивний niдxiд - наявність перешкод для економічної активності окремих груп населення, де вся влада знаходиться в руках вузького кола місцевих еліт, блокування участі населення (або окремих груп) у процесі управління, формалізованість процесу врядування та недієвість дорадчих і консультативних органів, в місцевих управлінців переважають особисті та корпоративні інтереси над інтересами громади.

Як для окремої громади, так і для всього регіону необхідним $є$ вироблення комплексної стратегії розвитку з урахуванням розширених можливостей місцевого самоврядування, основою якої має стати алгоритм досягнення трьох взаємопов'язаних стратегічних цілей: використання наявних конкурентних переваг; виявлення та розкриття прихованого потенціалу громад і регіону (умовно це виглядає, як пошук нових шляхів і можливостей до зростання); активізаиія дій на слабких $i$ проблемних ділянках (подолання системних недоліків в управлінні, соціально-економічній сфері, господарстві).

У випадку Закарпаття таке планування має враховувати не тільки економічні та управлінські аспекти, але й географічні та соціокультурні особливості регіону. Це безпосередньо впливає на органи місцевого самоврядування, які в певних сферах змушені боротися з низкою «хронічних» проблем регіону різного характеру - від «депресивності» гірських регіонів до збереження балансу в етнонаціональних відносинах, але після розширення повноважень мають можливість максимізувати користь від використання існуючих та потенційних конкурентних переваг. При цьому важливе значення має використання ресурсу «інклюзивності» - широке залучення органів самоорганізації населення, експертно-наукового та бізнес-середовища в рамках цілей стимулювання реалізації потенціалу громад до розвитку, їх взаємодії між собою.

Важливим $\epsilon$ й той факт, що значну частину (понад 80\%) Закарпаття складають гірські території, для яких здебільшого характерні логістичні та інфраструктурні проблеми, низький рівень інвестиційної привабливості, а також соціальні проблеми через високі рівні безробіття та трудової міграції. Загалом можна назвати цю ймовірну 
загрозу як збереження, так і посилення асиметрій в розвитку між гірськими та рівнинними територіями.

При цьому проблема є об'єднуючою характеристикою не тільки для громад Закарпаття, але й для значної частини територій регіону українських Карпат (окремих районів Львівської, Івано-Франківської та Чернівецької областей), що стало однією 3 передумов формування «Державної програми розвитку регіону українських Карпат на 2020-2022 роки» 3 урахуванням «Концепції розвитку гірських територій українських Карпат», яка серед іншого передбачає розширення підтримки місцевих громад на зазначених територіях.

Недостатній ресурсний, логістичний та інфраструктурний потенціали переважної більшості органів місцевого самоврядування гірських територій істотно ускладнюють реалізацію власних i делегованих повноважень і зумовлюють зниження якості та доступності адмінпослуг, низький рівень інвестиційної привабливості, міграційні процеси та втрату кваліфікованої робочої сили.

При цьому запроваджені з 2015 року нові механізми горизонтального вирівнювання місцевих бюджетів (вирівнювання дохідної частини адміністративно-територіальних одиниць) разом 3 іншими прогресивними рішеннями щодо збільшення дохідної частини місцевих бюджетів створили умови для появи у громад гірських територій необхідного фінансового ресурсу². В підсумку територіальні одиниці підвищили рівень інвестування за найбільш необхідними напрямами 3 допомогою бюджетного фінансування та шляхом залучення зовнішніх інвестицій. Зокрема, вітчизняні й іноземні інвестори відреагували на підвищення фінансового та управлінського потенціалу окремих територій відповідним капіталовкладеннями. Також територіальні одиниці змогли змінити структуру капітальних інвестицій за джерелами фінансування в аспекті зростання частки інвестицій за рахунок місцевих бюджетів при зниженні частки інвестицій, здійснених коштом державного бюджету.

Втім розширення бюджетів та залучення інвестицій поки що не призвело до відчутних результатів у подоланні або навіть пом'якшенні внутрішньо-регіональних та міжрегіональних диспропорцій ${ }^{3}$. Це, зокрема, пов'язано з істотними втратами кваліфікованої робочої сили та іншими наслідками трудової міграції, які негативно впливають на

2 Децентралізація в Україні та іiі вплив на соціально-економічний розвиток територій: методичні підходи та результати оцінювання : наукова доповідь / наук. ред. д. е. н., проф. Сторонянська І.З. Львів : ІРД НАНУ, 2018. 144 с.

3 Децентралізація в Україні та їі вплив на соціально-економічний розвиток територій: методичні підходи та результати оцінювання : наукова доповідь / наук. ред. д. е. н., проф. Сторонянська І.3. Львів : ІРД НАНУ, 2018. 144 с. 
можливості як регіону, так i окремих громад до соціальноекономічного зростання. Як наслідок - зниження конкурентоспроможності громад прикордоння та необхідність діяти в умовах жорсткої конкуренції за робочу силу 3 боку більш розвинених європейських регіонів-роботодавців. Відсутність скоординованої та ефективної політики в аспекті вирішення проблем регіону в довгостроковій перспективі може не тільки не вирішити, але й посилити «депресивність» територій, збільшити регіональні диспропорції.

Низка об'єктивних причин трудової міграції (низький рівень життя в Україні та значно менші заробітні плати, ніж у країнах Свропи) не можливо подолати виключно на місцевому рівні, тому в цьому контексті йдеться про використання наявних засобів для активізації розвитку місцевих господарств і підприємств, створення кластерів (наприклад, туристично-рекреаційних), а також заохочення трудових мігрантів інвестувати кошти у власні бізнес-ініціативи та сприяти розвитку власної громади.

Розвиток Закарпаття та інших регіонів детермінований соціальноекономічними наслідками пандемії COVID-19 внаслідок адміністративних та санітарних обмежень під час карантину. Зокрема, варто згадати про особливу «чутливість» до карантину підприємств туризму та рекреації, готельно-ресторанного бізнесу, що має істотні наслідки для регіону.

До умовних «факторів ризику» можна віднести i наявність територій iз поліетнічним складом населення на прикордонні, що зумовлює низку проблемних питань в етнонаціональних відносинах $\mathrm{i}$ навіть призводить до напруженості на міждержавному рівні (наприклад, україно-угорські суперечності, блокування Будапештом комісії «Україна-НАТО»).

Аналіз проблемних ділянок, а також визначення існуючих та потенційних конкурентних переваг регіону створюють орієнтири для формування алгоритму дій щодо розкриття внутрішнього потенціалу громад, який базується на розширенні повноважень місцевого самоврядування та зміцненні фінансово-бюджетної спроможності громад щодо вирішення завдань місцевого значення. Аналіз драйверів розвитку регіону західного прикордоння та його проблемних ділянок свідчить про взаємопов'язаність використання конкурентних переваг (включно виявлення нових переваг), подолання системних проблем i цілей євроінтеграції, вироблення узгодженої політики реалізації потенціалу розвитку прикордоння. 


\section{2. Посилення кооперації між громадами та сприяння їх участі в транскордонному співробітництві}

Помилковим $\epsilon$ аналіз місцевих громад як окремо взятої одиниці, не пов'язаної з іншими. Важливим $\epsilon$ встановлення сталих функціональних зв'язків між громадами, а також активізація міжтериторіальної та міжмуніципальної співпраці. Тому невід'ємним компонентом посилення вигод децентралізації є вдосконалення існуючих та пошук нових форм співпраці між громадами. Важливо й ініціювати формування проєктів та ініціатив щодо посилення координації у застосуванні суб' єктами місцевого самоврядування єдиного підходу та узгоджених спільних дій щодо подолання соціальних та економічних наслідків пандемії COVID-19, активізації потенціалу розвитку прикордонних територій за допомогою транскордонного співробітництва в «посткарантинних умовах».

У випадку Закарпаття слід констатувати нижчі показники інтенсивності співпраці між територіальними громадами, якщо брати як індикатор кількість укладених договорів між громадами та кількість громад, які скористалися інструментом міжмуніципального співробітництва. Йдеться про суттєвий «розрив» між Закарпатською областю та середніми показниками по країні, показниками областей-лідерів Полтавською та Вінницькою (Таблиця 1), що, очевидно, зумовлено «буксуванням» процесів добровільного об'єднання громад (станом на червень 2020 в Закарпатті створено 17 об'єднаних територіальних громад. За цим показником область $є$ «аутсайдером» в Україні).

Законодавством визначено можливість для територіальних громад на договірній основі об'єднувати свої зусилля та ресурси для вирішення місцевих проблем або роботи над досягненням цілей, які становлять спільний інтерес, спираючись на положення Конституції України та Закону України «Про співробітництво територіальних громад». Так, Т. Татарчук підкреслює, що співпраця є характерною для децентралізованої територіальної організації влади, яка полягає у взаємопов'язаності рівня автономії громад та обсягу можливостей до співпраці між ними ${ }^{4}$. Практична реалізація основних положень законодавства про співробітництво громад продемонструвала, що у процесі децентралізації низка локальних проблем вирішується шляхом співфінансування комунальних підприємств, впровадження громадами спільних проєктів, спрощення процесу надання адміністративних послуг і покращення життя населення.

4 Татарчук Т. Співробітництво територіальних громад: нові можливості для розвитку. Буковинський вісник державної служби та місиевого самоврядування. URL: http://buk-visnyk.cv.ua/misceve-samovryaduvannya/1362/. 
Співробітництво між громадами (станом на 10.01.2020)

\begin{tabular}{|c|c|c|c|c|c|}
\hline Область & 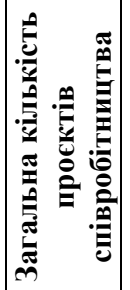 & 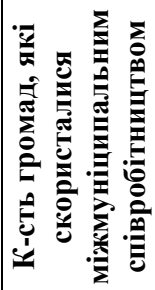 & $\begin{array}{l}\hat{E} \\
\hat{\tilde{J}} \\
\hat{\sigma} \\
0\end{array}$ & 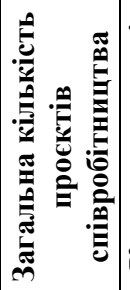 & 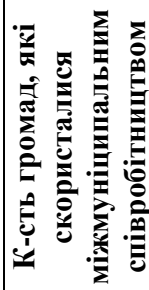 \\
\hline Вінницька & 95 & 169 & Миколаївська & 3 & 5 \\
\hline Волинська & 27 & 37 & Одеська & 2 & 9 \\
\hline Дніпропетровська & 12 & 29 & Полтавська & 109 & 283 \\
\hline Донецька & 2 & 5 & Рівненська & 16 & 27 \\
\hline Житомирська & 38 & 77 & Сумська & 50 & 60 \\
\hline Закарпатська & 4 & 10 & Тернопільська & 12 & 21 \\
\hline Запорізька & 9 & 27 & Харківська & 25 & 80 \\
\hline Івано-Франківська & 12 & 39 & Херсонська & 4 & 11 \\
\hline Київська & 8 & 9 & Хмельницька & 11 & 25 \\
\hline Кіровоградська & 11 & 17 & Черкаська & 33 & 91 \\
\hline Луганська & 4 & 9 & Чернівецька & 6 & 14 \\
\hline Львівська & 23 & 78 & Чернігівська & 14 & 56 \\
\hline \multicolumn{4}{|c|}{$\begin{array}{l}\text { Всього проєктів співробітництва / } \\
\text { середня кількість на область }\end{array}$} & \multicolumn{2}{|c|}{$530 / 23$} \\
\hline \multicolumn{4}{|c|}{$\begin{array}{c}\text { Всього ініціатив міжмуніципального } \\
\text { співробітництва / середня кількість на область }\end{array}$} & \multicolumn{2}{|c|}{1188 / 50} \\
\hline
\end{tabular}

Це розширює можливості кооперації між громадами в аспектах стимулювання господарської активності та реалізації проєктів із вдосконалення існуючої та розбудови нової інфраструктури. В цьому випадку важливо використовувати кластерний підхід, який успішно застосовується в розвинених країнах Європи, до активізації економічного розвитку на локальному рівні, що передбачає координацію дій із мобілізації та використання наявних у місцевих громад ресурсів, стимулювання розвитку перспективних галузей

5 Моніторинг процесу децентралізації влади та реформування місцевого самоврядування (станом на 10 січня 2020 року). URL: https://decentralization.gov.ua/ uploads/library/file/526/10.01.2020.pdf. 
(включно наукомістких та інноваційних), інтеграцію господарського, кадрового, наукового потенціалів кожної громади 6 .

Реалізацію кластерного підходу в рамках співпраці між місцевими громадами Закарпаття можна проаналізувати на прикладі сприяння розвитку туристично-рекреаційних зон. Зважаючи на конкурентні переваги іміджу Закарпаття як регіону зі сприятливим для відпочинку «екологічним фоном» та умов для розвитку туризму, рекреації, курортно-оздоровчих зон перспективним $€$ створення туристичнорекреаційних кластерів. Йдеться про розробку просторових моделей кластерного типу як точок економічного зростання ОТГ та засобу протидії масовій трудовій міграції, подолання критичного рівня відставання в розвитку гірських територій, забезпечення згуртованості громад і регіону.

Насамперед важливою $є$ мобілізація зусиль і ресурсів ОТГ у створенні та підтримці розвитку туристично-рекреаційних кластерів на основі природних зон та/або історико-архітектурних пам'яток, в рамках чого можна залучати приватні інвестиції, що дасть стимул для розвитку місцевого бізнесу (торгівлі, організації відпочинку, тимчасового розміщення, закладів харчування).

Необхідною є промоція та інформаційний супровід таких кластерів при загальній координації та підтримці обласної влади, що має включати обов'язкові елементи створення інтерактивних карт, 3Dтурів, відповідних інформативних сайтів, рекламу та просування в популярних відеохостингах ("YouTube"), соціальних мережах ("Facebook", "Instagram") та кінематографi, спираючись на успішний досвід серіалу «Чорнобиль» і туристичний «бум», який він спричинив. Необхідною також є взаємодія органів місцевого самоврядування при вирішенні логістичних проблем (особливо в гірській місцевості) та створення відповідної інфраструктури.

Зважаючи на розширення повноважень громад, окремим напрямом слід виділити розвиток транскордонних зв'язків в межах економічної, технологічної, інфраструктурної та гуманітарної площини. Це передбачає реалізацію комплексу дій на локальному рівні, при цьому необхідною $є$ координація з боку Міністерства закордонних справ. Сприятливими чинниками тут $€$ наявність спільних кордонів із $€$ С (Закарпатська область межує відразу з чотирма країнами-членами $\mathrm{CC}$ ), транскордонні зв'язки та кооперація із європейськими країнами, яка здійснюється в різних формах (участь у таких асоціаціях як Єврорегіон

${ }^{6}$ Калашнікова О. Кластерний підхід до розвитку об'єднаних територіальних громад: аналітична записка. ВГО «Асоиіація сприяння самоорганізації населення». URL: https://issuu.com/irf_ua/docs/dp-2016-28. 
«Карпатський», Європейське об’єднання територіального співробітництва «Тиса», реалізація спільних ініціатив в рамках операційних програм транскордонного співробітництва).

При цьому на рівні ОТГ все ще наявні перешкоди у вигляді недостатньої поінформованості щодо можливостей та механізмів участі в транскордонному співробітництві, зокрема стереотипів, пов'язаних зі сприйняттям цієї сфери виключно як джерела грошових ресурсів. До того ж відчутним $є$ фактор недостатнього кадрового потенціалу. Зокрема, йдеться про фахівців, які володіють необхідним практичним досвідом i навичками проєктного менеджменту, підготовки аплікаційних форм та інших документів, взаємодії із міжнародними фондами та організаціями-грантодавцями.

В рамках співпраці між українськими громадами та відповідними суб'єктами сусідніх країн, а також європейськими установами та фондами ймовірним $\epsilon$ розширення можливостей для спільного управління, інвестування проєктів, спрямованих на вдосконалення та оптимізацію роботи об'єктів прикордонної інфраструктури, «екологічних» ініціатив, спільних кроків для активізації потенціалу економічного зростання прикордонних регіонів, освітньої мобільності та наукового туризму, культурного та духовного розвитку національних спільнот і меншин.

Окремо слід підкреслити значення політики сприяння взаємодії господарських суб'єктів, які локалізовані на транскордонних територіях двох або більше держав-сусідів (де місцеві громади можуть відігравати провідну роль) в межах використання такої форми транскордонної співпраці, як створення європейських об'єднань територіального співробітництва. Згідно Закону України «Про транскордонне співробітництво» - це об'єднання суб'єктів транскордонного співробітництва України та відповідних суб'єктів сусідніх держав-членів Європейського Союзу зі статусом юридичної особи відповідно до національного законодавства держави-члена Європейського Союзу, на території якої $є$ його місцезнаходження.

Використання такого інструменту розширює можливості громад за такими напрямами:

- Спільне просторове планування та розробка просторових моделей кластерного типу як точок економічного зростання.

- Тісна співпраця та посилення господарських, управлінських, наукових, освітніх, культурних взаємозв'язків між місцевими громадами Закарпаття та сусідніх країн-членів СС (це важливо з огляду на євроінтеграційні прагнення України). 
- Розвиток практик та використання інструментів транскордонного співробітництва для вирішення найбільш гострих проблем, які $\epsilon$ спільними для сусідніх регіонів прикордонної зони.

\section{3. Забезпечення згуртованості громад і протидія регіональним ризикам}

Згуртованість місиевих громад як один із видів соціальної згуртованості у спрощеному вигляді виражається крізь низку індикаторів. Насамперед свідченням згуртованості локальних спільнот $\epsilon$ відсутність істотних протиріч і відсутність (або їх несуттєвий вплив) конфліктогенних факторів всередині громади або між громадами на основі політичних, економічних, соціально-майнових, етнонаціональних та релігійних ознак. Показником незгуртованості слід вважати соціальну роз'єднаність громади (ізоляцію окремих груп населення) та наявність відкритих конфліктів між різними групами (наприклад, між місцевим населенням і внутрішньо переміщеними особами) або між громадами.

В цьому контексті слід підкреслити необхідність наявності достатнього лідерського потенціалу та легітимності місцевої влади для мобілізації громад і наявних у них ресурсів з метою вирішення проблем місцевого значення та реалізації важливих для населення завдань. До цього доречно додати потребу в достатньому «соціальному капіталі» як комплексі специфічних «ресурсів» - високий рівень взаємодовіри та готовність членів громади допомагати один одному.

Об’єктивним наслідком зазначеного вище $\epsilon$ спроможність організації протидіяти загрозам і впливу непрогнозованих факторів. Показовий та все ще актуальний приклад - згуртованість громади в умовах пандемії COVID-19 та карантинних обмежень: боротьба 3 поширенням інфекції, ізоляційні та санітарно-епідеміологічні заходи, резистентність до поширення фейкової інформації та «медіапровокацій», відновлення господарської та підприємницької активності в «посткарантинних» умовах розвитку економіки.

Виникає необхідність згуртування та посилення взаємодії всередині громади та між громадами 3 метою подолання наслідків кризи, відновлення господарства та соціально-економічного розвитку після карантину; протидії зниженню ділової та господарської активності та пов'язаних із карантином санітарних та адміністративних обмежень; посилення рівня підготовленості місцевих громад до потенційних надзвичайних ситуацій (хоча все ще ймовірний повторний спалах COVID-19 протягом осені-зими 2020 року).

Крім того, розширені можливості місцевого самоврядування необхідно використовувати за напрямами, які визначають 
довгострокові орієнтири розвитку регіону (знову ж таке йдеться про специфіку Закарпаття) за напрямом консолідації зусиль і кооперації громад у подоланні наслідків стихійних лих (насамперед повеней), наслідків для критичної інфраструктури на місцях.

Окремо варто підкреслити, що у випадку Західного регіону важливим $\epsilon$ врахування специфіки прикордонних поліетнічних територій, особливо територій, де національні спільноти превалюють у структурі населення (наприклад, Берегівський район Закарпатської області із переважаючими угорською та угорськомовною спільнами), що має передбачати ефективне включення представників національних спільнот у процеси кооперації між громадами (насамперед для залучення національних спільнот до освітніх, наукових і культурних ініціатив, безбар'єрності їх участі в процесі управління) 3 метою досягнення згуртованості та соціальної стійкості як окремого регіону, так і країни загалом ${ }^{7}$.

3 огляду на наведені вище тези та 3 урахуванням нових можливостей місцевого самоврядування, на часі $\epsilon$ підтримка регіональних ініціатив, спрямованих на формування стійких зв'язків між представниками різних соціальних груп як чинника соціальної згуртованості та попередження конфліктів, що має включати:

- достатній рівень залучення населення громади до процесів ухвалення рішень на місцевому рівні та вирішення актуальних проблем, невід'ємним елементом чого є ефективне функціонування форм громадського обговорення рішень (робота консультаційнодорадчих органів) при прозорості виборчого процесу;

- сприяння самоідентифікації осіб на рівні громади та інтегрованість в український національний простір;

- проведення наукових проєктів і публічних заходів, фестивалів та ярмарок із залученням представників національних спільнот Закарпаття.

Як слушно зауважує Н. Павлюк, практична реалізація принципів сучасної ефективної управлінської системи на місцевому рівні можлива лише шляхом перерозподілу владних функцій та обов'язків від центральних органів державної влади ${ }^{8}$. В Україні таке завдання ускладнюється внаслідок регіональних факторів, які після корінних трансформацій існуючої управлінської системи зможуть стати

7 Головка А.А. Безпекові виклики в поліетнічних регіонах (на прикладі Закарпаття та Буковини). Гілея (науковий вісник). 2019. № 150, С. 23-27.

${ }^{8}$ Павлюк Н.В. Децентралізація влади як основа вдосконалення організаційноправового механізму публічного управління. Ефективність державного управління. 2016. № 4, C. 183-190. 
причиною потенційних ризиків дезінтеграційних тенденцій i недостатнього рівня керованості процесами в окремих регіонах.

До таких регіональних факторів доречно відносити прикордонний статус регіону (особливо, якщо він в минулому перебував у складі сусідньої держави), поліетнічний і поліконфесійний склад населення, наявність внутрішньо-регіональних суперечностей між представниками місцевої еліти. Регіон Закарпаття характеризується всіма згаданими вище факторами:

- Знаходиться в межах західного прикордоння і межує із чотирма країнами-членами СС (єдиний в Україні). Історично Закарпаття входило до складу низки держав (Австрійська імперія Габсбургів, а пізніше Австро-Угорщина, Чехословацька Республіка, Угорщина, CPCP).

- Для регіону характерна «строката» соціальна структура - на його території компактно проживають національні спільноти та меншини (угорці, румуни, роми, поляки, німці, євреї).

- Суттєвий влив місцевих еліт та «кланів» $є$ однією 3 головних ознак суспільно-політичного життя регіону 9 .

3 огляду на соціальну та культурну ексклюзивність Закарпаття, доречно підкреслити наявність сприятливої основи для формування та подальшого просування концептів «окремішності» регіону, його «унікальної» ідентичності, яка може слугувати «фасадом» для зародження та посилення сепаратистських настроїв. Згадані вище концепти «окремішності» посилися внаслідок російської агресії проти України і в умовах складної політичної ситуації стали однією з причин загострення міжетнічної ворожнечі.

Прикордонні поліетнічні території характеризуються наявністю додаткових факторів ризику через вплив сусідніх держав (у випадку Закарпаття показовим прикладом $\epsilon$ наявність україно-угорських суперечностей навколо ситуації із громадою закарпатських угорців). При цьому такі концепти потенційно можуть стати одним зі складових компонентів «гібридної війни» і включати в себе цілі 3 дестабілізації ситуації в регіоні.

Частина експертів ${ }^{10}$, аналізуючи ризики децентралізації, підкреслює негативний вплив чинників наближеності представників влади до місцевих груп інтересів, неформальність відносин, залежність місцевих чиновників від політиків, вибірковість у прийнятті рішень і дотриманні

9 Головка А.А. Безпекові виклики в поліетнічних регіонах (на прикладі Закарпаття та Буковини). Гілея (науковий вісник). 2019. № 150, С. $23-27$.

10 Бризіцький М. Ризики децентралізації. Децентралізація в Украйні. URL: https://decentralization.gov.ua/news/11589. 
законодавства (що часто межує із виявами свавілля), «керованість» місцевими 3МІ.

Продовжуючи цю думку, варто підкреслити, що розширення повноважень органів місцевого самоврядування дає їм більше важелів впливу на регіональну політичну ситуацію, але не убезпечує регіон від посилення «зовнішнього впливу» третіх сторін, звужує можливості центру впливати на політичні процеси на периферії. Тобто, з'являються передумови для посилення впливу сусідніх держав на місцевий «Порядок денний» шляхом сприяння створенню групи лоббістів (депутатів місцевих рад, громадських i політичних організацій, регіональних 3MI) у місцевих громадах, збереження «негласного» впливу місцевих еліт на характер управлінських процесів і прийняття рішень.

У такому випадку необхідним є забезпечення постійного зв'язку між представниками центральних і місцевих органів виконавчої влади iз місцевим самоврядуванням, органами самоорганізації населення, представниками національних спільнот. Слід посилити роль «діалогових майданчиків» (спільних робочих груп, селекторних нарад iз використанням телекомунікаційних засобів зв'язку) в процесах визначення орієнтирів розвитку регіону та планування. Важливим $\epsilon$ уникнення «формалізованості» цього процесу, коли процес діалогу зводиться виключно до чергових формальних i безрезультатних обговорень виключно для звітування перед державним керівництвом i збереження позитивного іміджу в очах громадськості.

До того ж органи місцевого самоврядування спільно 3 органами державної влади мають можливість попередити появу ситуацій, коли посередником у вирішенні проблем національних меншин $є$ третя сторона (наприклад, посередництво та вплив Будапешта в питаннях культурних і мовних прав угорців Закарпаття).

Важливого значення в цьому контексті набуває проведення спільного (із залученням представників національних спільнот) форуму, присвяченого вирішенню спільних для регіону проблем, що надає можливості для тісної співпраці регіональних суб'єктів і центральних органів влади, консолідації зусиль всіх громад у вирішенні нагальних проблем. Наприклад, питання соціальноекономічного благополуччя регіону, зокрема транскордонної співпраці як драйвера розвитку, що потребуватиме залучення місцевих i зарубіжних підприємців, домогосподарств (в тому числі представників угорських, румунських та інших громад краю). 


\section{ВИСНОВКИ}

1. Спираючись на наведений вище матеріал, доречно підкреслити, що активізація розвитку регіону Закарпаття (як і інших регіонів) потребує утвердження «інклюзивної моделі врядування» (рівні можливості для участі у врядуванні, функціонування необхідних інститутів, які дають рівні стартові можливості щодо господарської активності, соціального підприємництва), що має замінити елементи «екстрактивної моделі» (концентрація влади у вузького кола місцевої еліти, наявність бар'єрів щодо соціально-економічної активності).

3 наведених матеріалів вбачається, що орієнтація на «інклюзивність» разом зі зміною поточної моделі взаємовідносин «центр - регіон» та пов'язані з цим зміни в питаннях врядування зумовлюють також відповідні чіткі правові гарантії, формування нових програмних і стратегічних документів (або внесення змін до вже існуючих документів), присвячених регіональній політиці. В такому випадку очевидною $є$ взаємопов'язаність всіх рівнів врядування. Збільшення обсягів місцевих бюджетів і розширення повноважень місцевих рад хоч і створює простір для ініціативності, але активізація всестороннього розвитку передбачає взаємопов'язаність цілей секторального та просторового розвитку.

2. Диспропорції соціально-економічного розвитку між регіонами та внутрішньо-регіональні асиметрії, актуальні проблеми регіонів (зокрема трудова міграція, неефективність місцевого менеджменту), а також євроінтеграційні прагнення України підкреслюють необхідність інституційних та правових перетворень, осучаснення поточних механізмів регіональної політики, зокрема в аспекті відносин між центром і прикордонними територіями.

Важливою $є$ також відмова від архаїзмів та стереотипів у сприйнятті прикордонних і гірських територій (зокрема Закарпаття) як виключно депресивних і дотаційних, відхід від принципу орієнтування місцевих еліт на задоволення виключно індивідуальних та корпоративних інтересів, що на практиці призводило до блокування децентралізації. Зазначеним вище специфічним характеристикам слід протиставляти «прогресизм» i новації у сегменті соціального та економічного зростання, а також посилення взаємодії «центр-периферія» в питаннях вироблення ефективних механізмів врядування, унормування актуальних проблем, надання адміністративних послуг.

3. Актуальні суспільно-політичні процеси у прикордонних регіонах України засвідчують зростаюче значення самоорганізації локальних громад та їх згуртованість в умовах посилення взаємозалежності країн i регіонів, нових викликів у сфері врядування, господарської діяльності, соціальних відносин. Особливо відчутними такі процеси $\epsilon$ на 
Закарпатті, яке через низку специфічних ознак характеризується наявністю ризиків посилення зовнішнього впливу та загострення протистояння між групами регіональних еліт на тлі політизації етнічних спільнот.

Високо ймовірним $є$ збереження негативного впливу згаданих вище ризиків навіть після завершального етапу реформи місцевого самоврядування та територіальної організації влади. Їх динаміка буде детермінована зовнішнім впливом i рівнем активності місцевих політичних та громадських організацій, виявлятися в ізоляції окремих громад, міжрегіональних суперечностях і навіть включенні всього регіону або окремих територій у сферу політичного впливу сусідніх країн. За такої умови посилюється тиск на органи місцевого самоврядування в питанні збереження ними реальної автономності, а також зростає значення стратегічних комунікацій між ланками політичної влади в Україні.

Як у випадку Закарпаття, так і інших прикордонних поліетнічних територій (наприклад, Чернівецька, Одеська області) набуває актуальності реалізація принципів проактивного підходу на місцевому рівні як основи соціальної стійкості. Зокрема, йдеться про застосування такого підходу в питаннях забезпечення етнонаціональних та міжконфесійних відносин, забезпечення участі всіх соціальних, етнічних / національних і конфесійних груп в житті громади, де важливим є використання інклюзивної політики.

\section{АНОТАЦІЯ}

Висвітлено бачення автора щодо можливостей місцевого самоврядування активізувати розвиток громад і регіону, протидіяти актуальним загрозам в умовах нової територіальної організації влади. В якості прикладу було вибрано регіон Закарпаття, у фокусі уваги були механізми співробітництва, взаємокоординації локальних спільнот, мобілізації ресурсів, використання наявних i пошук нових конкурентних переваг, а також подолання системних проблем регіону чи окремих територій. Як результат було виокремлено та охарактеризовано потенційні засоби реалізації внутрішнього потенціалу громад і регіону, забезпечення їх згуртованості на основі розширених управлінських та бюджетних можливостей місцевого самоврядування.

Насамперед було виокремлено потенційні засоби стимулювання взаємодії між громадами та реалізацію кластерного підходу, посилення міжнародної суб' єктності громад і регіону шляхом заохочення участі в ініціативах транскордонного співробітництва, політику згуртування громад, підвищення якості локального менеджменту. Підкреслено 
необхідність використання інклюзивного підходу (в широкому розумінні) - забезпечення таких умов, за яких всі групи населення мають рівні можливості для участі в процесі врядування, наявна безбар'єрність економічної та соціальної активності. Запропоновано перелік кроків щодо стимулювання розвитку Закарпатської області 3 можливістю їх закріплення в цільових програмах.

\section{ЛIТЕРАТУРА}

1. Acemoglu D., Robinson J. Why Nations Fail: The Origins of Power, Prosperity and Poverty. New-York: Crown Publishers. URL: http://norayr.am/ collections/books/Why-Nations-Fail-Daron-Acemoglu.pdf.

2. Бризіцький М. Ризики децентралізації. Децентралізація в Україні. URL: https://decentralization.gov.ua/news/11589.

3. Головка А.А. Безпекові виклики в поліетнічних регіонах (на прикладі Закарпаття та Буковини). Гілея (науковий вісник). 2019. № 150 , С. 23-27.

4. Децентралізація в Україні та ï̈ вплив на соціально-економічний розвиток територій: методичні підходи та результати оцінювання: наукова доповідь / наук. ред. д. е. н., проф. Сторонянська І.З. Львів : ІРД НАНУ, 2018. $144 \mathrm{c}$.

5. Калашнікова О. Кластерний підхід до розвитку об'єднаних територіальних громад: аналітична записка. ВГО «Асоціація сприяння самоорганізації населення». URL: https://issuu.com/irf_ua/docs/dp-2016-28.

6. Моніторинг процесу децентралізації влади та реформування місцевого самоврядування (станом на 10 січня 2020 року). URL: https://decentralization.gov.ua/uploads/library/file/526/10.01.2020.pdf.

7. Павлюк Н.В. Децентралізація влади як основа вдосконалення організаційно-правового механізму публічного управління. Ефективність державного управління. 2016. № 4, С. 183-190.

8. Татарчук Т. Співробітництво територіальних громад: нові можливості для розвитку. Буковинський вісник державної служби та місцевого самоврядування. URL: http://buk-visnyk.cv.ua/miscevesamovryaduvannya/1362/.

Information about authors: Holovka A. A., $\mathrm{PhD}$ in Political Science, Consultant of the National Institute for Strategic Studies 7-A, Pyrohova Str., Kyiv, 01030, Ukraine 